\title{
Countermeasure Against International Drug Crimes In The Perspective Of Indonesian Criminal Law
}

\author{
Poltak Siringoringo \\ Faculty of Law, Universitas Kristen Indonesia, Jakarta, Indonesia
}

\begin{abstract}
Circulation and use of narcotics and illegal drugs are massive crimes and can be categorized as "extraordinary crime" and become common enemies of this nation and even other nations in the world. Campaign and the formation of public opinion about the dangers of drugs must be done massively on all layers of society. This is part of the handling of drug crimes in Indonesia. Communities must be given a proper understanding of the negative effects of drugs both for users/users, dealers, who produce and store. This understanding starts from several phases namely what is the phase of drug prevention in society? What is the phase if it is already using drugs and putting drug users as victims? what is the phase of law enforcement against drug crimes? These phases must be campaigned on a massive scale so that people understand that things related to drugs have more negative impacts than positive effects. Collaboration with the international community in dealing with the dangers of drugs must also be carried out because drug trafficking networks to enter Indonesia cannot be separated through inter-state lines. Countries in the world must have the same perception and understanding that narcotics are a serious crime and need to be taken seriously by law enforcement agencies between countries.
\end{abstract}

Keywords: crime, narcotics, cross country.

\section{INTRODUCTION}

Crimes related to narcotics and dangerous drugs or commonly referred to as drugs are now so systematic and massive. Its users also vary from artists, state officials, community leaders, and even those who are very concerned about many State officials who were caught because of drugs. Even more dangerous has entered the school environment starting from Junior High School (JHS) to Higher Education. Drugs are a new style of colonialism in this millennial era because the target is productive young generations. The young generation who acted as the backbone of the nation that should have prepared themselves for the regeneration of the nation's leaders became damaged due to drugs. With the destruction of the nation's young generation, our nation cannot play a smart role in appearing in economic, political competition on an international scale, so that the impact is unconsciously that we will experience colonialism in economic and political terms.

Campaign and the formation of public opinion about the dangers of drugs must be done massively on all layers of society. This is part of the handling of drug crimes in Indonesia. The public must be given a correct understanding of the negative impact of drugs both for users/users, dealers, who produce and store. This understanding starts from several phases namely how is the phase of drug 
Siringoringo, P. (2020). Countermeasure Against International Drug Crimes In The Perspective Of Indonesian Criminal Law. Advances in Social Sciences Research Journal, 7(5) 251-269.

prevention in the community? What is the phase if it is already using drugs and putting drug users as victims? what is the phase of law enforcement against drug crimes?

These phases must be campaigned on a massive scale so that people understand that things related to drugs have more negative impacts than positive effects. Collaboration with the international community in dealing with the dangers of drugs must also be carried out because drug trafficking networks to enter Indonesia cannot be separated through inter-state lines. Countries in the world must have the same perception and understanding that narcotics are a serious crime and need to be taken seriously by law enforcement agencies among countries.

\section{Countermeasure for Drug Prevention Phase}

\section{1) Factors Causing Someone Use Drugs}

Based on the latest data from the National Narcotics Agency (BNN), in 2017 the number of drug addicts in Indonesia currently reaches approximately six million people. There are certain factors that cause a person to start using drugs, and eventually become addicted, including:

\section{a) Environmental influences}

The environment also plays an important role in the emergence of addiction. One of the most common reasons why someone is tempted to try to use drugs from outside influences, both directly and indirectly - especially people they often meet or idolize, including parents, friends, brothers, and even celebrities. We live in an era where drug use is openly discussed and even promoted by important people. This then influences curiosity and triggers the desire to experiment.

\section{b) Curiosity}

Curiosity is one of human instincts. Many teenagers become addicted to drugs because they are initiated by experiments with drugs and alcohol-based on curiosity as to what it feels like. Many teenagers even though they know that drugs are bad, do not believe it will happen to them so they decide to try. Some use drugs to get recognition of their social status, also to feel the same experience with their friends.

\section{c) Addiction due to accidental}

Some pain relievers are very easy to be misused because of their "sedating" effects, even in unintentional cases. One of them is opiates. Initially opiates (such as oxycodone, Percocet, Vicodin, or Fentanyl) are prescribed by doctors to deal with extreme pain. Opium drugs are indeed very effective for dealing with unbearable pain, for example during cancer therapy or post-surgical treatment. Some use ecstasy to relieve excessive anxiety symptoms in certain social situations. But over time, the body can develop a tolerance for the effects of this drug, so some people tend to increase the dose without the permission of the doctor. This is what causes them to inadvertently depend on the drug.

\section{d) Addicted by choice}

Many of us intentionally enjoy addictive substances, such as alcohol or nicotine from cigarettes. In most people, the love of alcohol does not cause addiction because they manage to balance or control themselves and find other alternatives, such as spending time with family or doing other hobbies. 


\section{e) The Look Be More Stylish}

Certain types of forbidden substances can make their uncle more brave, cool, confident, creative, relaxed, and so on. Cool effects seen by other people can become a trend in certain circles so that people who use prohibited substances will be called trendy, slang, fashionable, and so on.

\section{f) Group Solidarity}

A group of people who have a high level of kinship between members usually have a high value of solidarity. For example, if the chairman or some group members who influence the group use narcotics, then usually other members either forcefully or not being forced to take part in using narcotics to feel like a family in the same boat.

\section{g) Relieving the Pain}

Seseorang Relieveing the Pain: Someone who has an illness or disorder that can cause unbearable pain can make people become interested in shortcuts to treat their pain by using drugs and illegal substances.

\section{h) Solving the Problem}

Orang People who are veiled with lots of problems and want to run away from problems can fall into the lap of narcotics, drugs, or addictive substances so they can sleep well or get excited and then feel the problem resolved for a moment.

\section{i) Looking for Challenges/Risky Activities}

For people who are happy with activities that have a high risk of carrying out their actions. Some of them use illegal drugs to become the greatest, full of energy, and full of confidence.

\section{1) Negative Impact of Drug Use}

In general the effects of drug dependence/addiction can be seen on the physical, psychological, and social of a person/user.

\section{(a) Physical Impact:}

- There are disorders of the nervous system (neurological) such as; convulsions, hallucinations, disturbance of consciousness, peripheral nerve damage, and so on.

- Occurrence of disorders of the heart and blood vessels (cardiovascular) such as; acute infections of the heart muscle, circulatory disorders, and so on.

- Occurrence of skin disorders (dermatological) such as; Prognosis, allergies, eczema, and so on.

- The occurrence of disorders of the lungs (pulmonary) such as; suppression of respiratory function, difficulty in breathing, hardening of lung tissue, and so on.

- Have headaches, nausea, and vomiting, nausea, increased body temperature, wasting of the heart and difficulty sleeping

- Disorders of reproductive health in the form of disorders in endocrine such as; decreased function of reproductive hormones (estrogen, progesterone, testosterone) and sexual function disorders.

- Disorders of reproductive health in women of childbearing age such as; changes in menstrual cycles/menstruation, irregular menstruation/menstruation, and amenorrhea (no menstruation occurs). 
- For drug users through needles by taking turns will be at risk of contracting diseases such as; hepatitis B, C, and HIV / AIDS which until now there is no cure. • If there is an overdose of drug use, it will have fatal consequences, i.e. death.

- The occurrence of malnutrition, skin diseases, tooth decay, and venereal diseases.

\section{(b) Psychic Impact :}

- There is a change in mental-emotional life in the form of abnormal behavior disorders.

- Severe addicts and duration of drug use will lead to fashional "Amoy" syndrome. If you break up the amphetamine class of drugs it can cause depression to suicide.

- Regarding mental function, there will be a disturbance of perception, thinking, creation, and emotion.

- Work slow, careless, nervous, and nervous.

- Confidence is lost, apathetic, delusional, and suspicious.

- Aggressive, acting ferociously and brutally out of consciousness.

- Lack of concentration, feeling depressed, and upset.

- Tend to hurt yourself, feel insecure, and so on.

\section{(c). Social Impact:}

- The occurrence of mental-emotional disorders will interfere with its function as a member of the community, work, school, and other social functions/tasks.

- Acting wrongly, achievement ability decreases, being fired/expelled from work,

- Relationships with family, close friends become tenuous.

- Anti-social, immoral, and ostracized by the environment.

The impact of drug use and drug abuse physically, psychologically and socially will potentially cause extraordinary illness and addiction if it cannot consume it (drugs), because there is a strong urge (psychologically) to get it, even though in various ways (justifying any means to get it) by violating applicable social norms.

These phenomena must be campaigned massively at all levels of society so that public opinion is formed together to understand that drugs are a crime and harm both users personally and social community.

\section{4). Transnational Drug Circulatory Crimes}

The crime of issuing narcotics and illegal drugs (narcotics) regarding cross-country licenses, bearing in mind producers, couriers, and victims can talk about different countries. For this reason, international cooperation is needed because it cannot be overcome by one country alone.

According to the 2014 UNODC (United Nations Office on Drugs and Crime) Report, the production and illicit trafficking of Narcotics was most dominant around the Laos, Myanmar, and Thailand regions which are the "Golden Triangle" together with China.

Given its geographical and demographic conditions, Indonesia has become one of the destination countries for narcotics distribution. Indonesia has placed drug crime as a high-risk crime and its handling requires extraordinary efforts. For this reason, Indonesia encourages international 
cooperation to increase efforts to tackle drug issues. At present there are 3 (three) anti-drug conventions, all of which have also been ratified by Indonesia, namely:

- Single Convention on Narcotic Drugs 1961 through Law No.8 of 1976;

- Convention on Psychotropic Substances 1971 through Law No.8 of 1996;

- Convention against the Illicit Traffic in Narcotic Drugs and Psychotropic Substances 1988 through Law No. 7 of 1997.

Indonesia's main interest in tackling drug trafficking and illicit trafficking is to prevent the flow of drugs into and out of their precursors. Indonesia is based on a balanced approach between 'supply and demand reduction', law enforcement and human rights protection, and comprehensive and integrated countermeasures.

At the multilateral level, Indonesia continues to play an active role in combating drug trafficking and illicit trafficking in various forums such as Commission on Narcotic Drugs, Special Session of the United Nations General Assembly on the World Drug Problem, Head of National Drug Law Enforcement for Asia Pacific, dan ASEAN Senior Officials on Drug Matters dan berbagai pertemuan lainnya di bawah kerangka $U N O D C$.

Indonesia will continue to support every effort to strengthen the role of UN agencies, increase coordination among stakeholders at international and regional levels, in an effort to tackle the narcotics problem in an integrated and comprehensive manner. Indonesia also supports one of the initiatives produced at the international forum, namely the eradication of drugs through alternative development approaches.

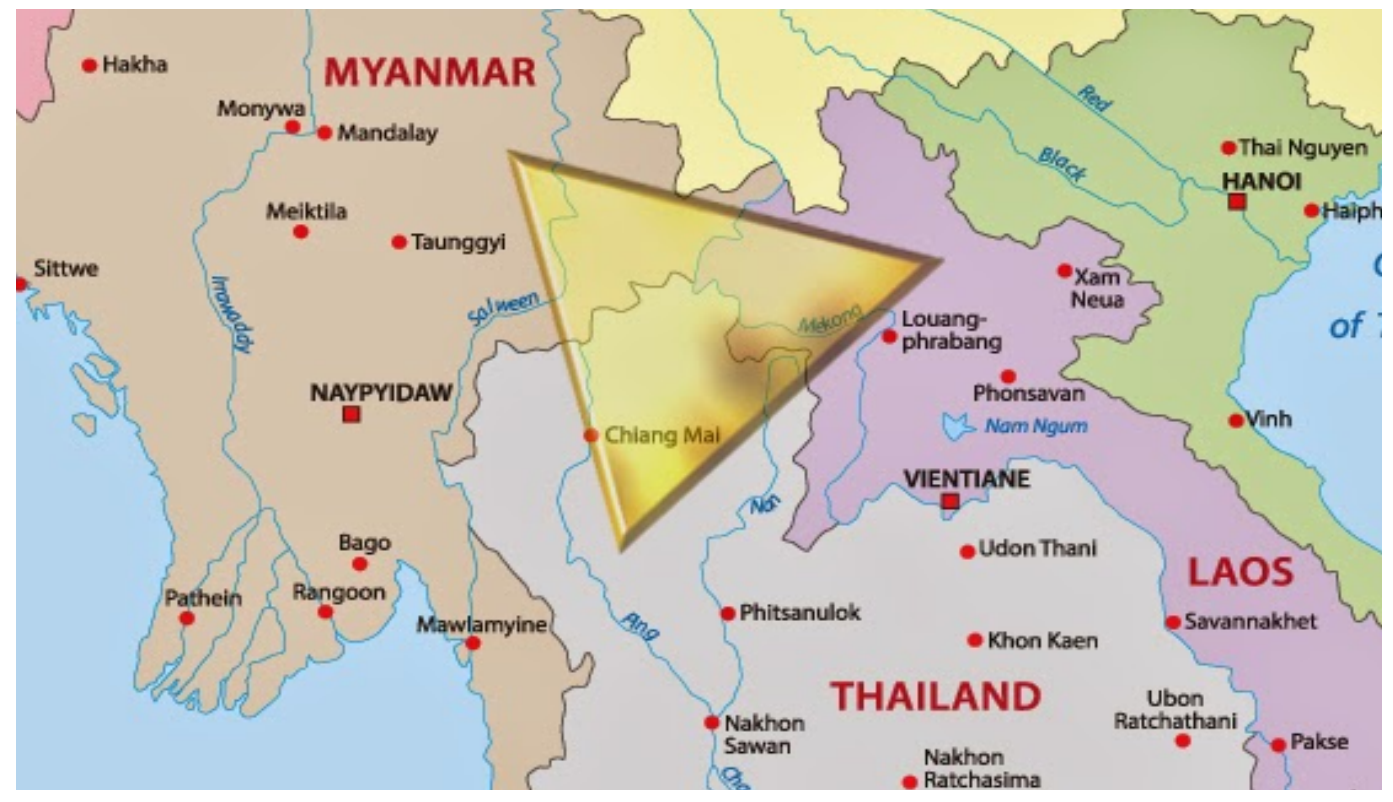

Figure 1. Map of the Golden Triangle of Drug Trafficking 


\section{Peta Jalur Penyelundupan Narkoba ke Indonesia}

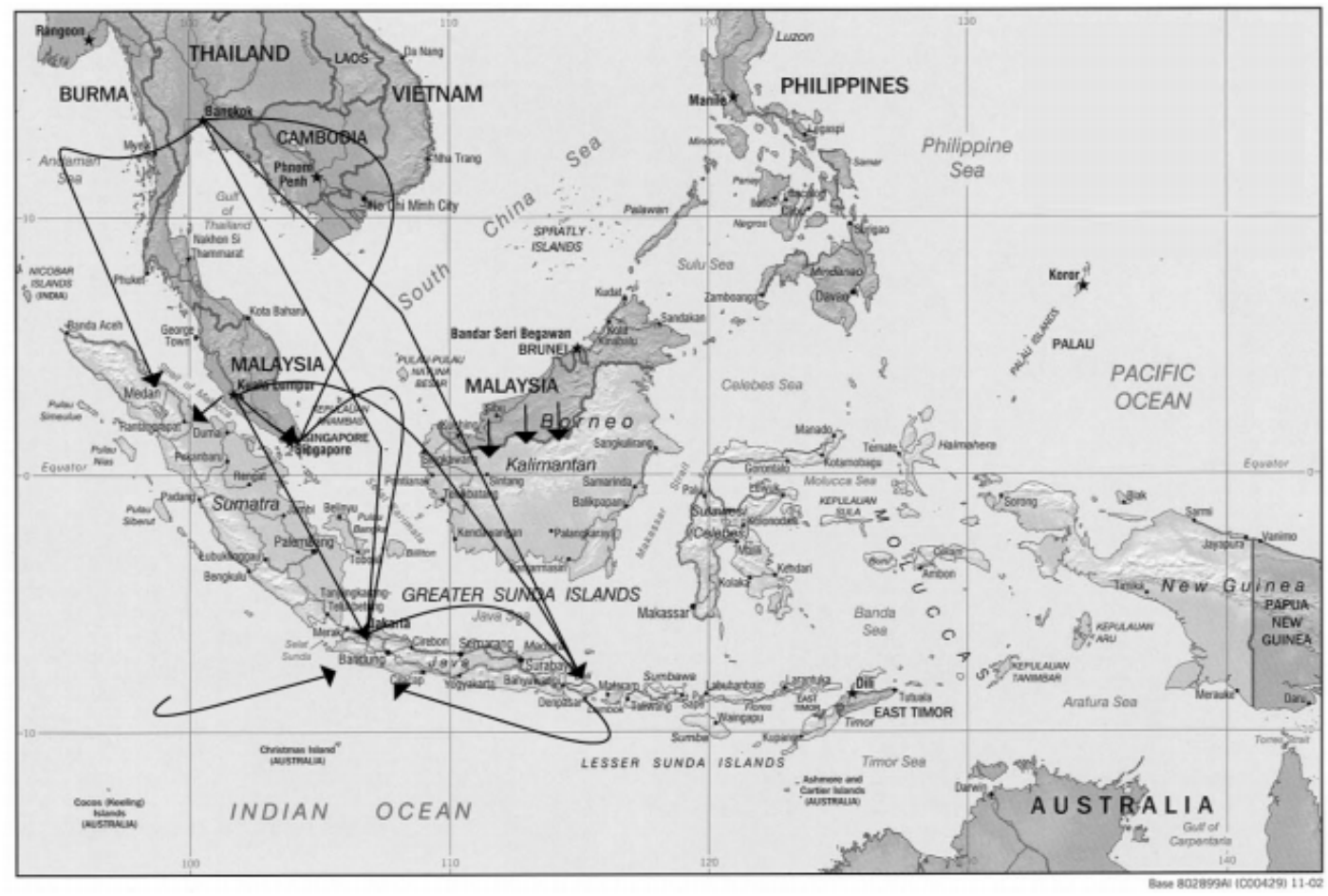

Keterangan: peta ini adalah gambaran sebagian jalur penyelundupan narkoba ke Indonesia yang dibuat berdasarkan data-data hasil penelitian 2014 .

The alternative development approach aims to reduce the planting of plants containing narcotic substances through development steps and increasing income in the community. Indonesia is implementing the Grand Design Alternative Development (GDAD) program in Aceh Province for the 2016-2025 period as a national pilot project.

International drug syndicates, as professional non-state actors, with various modes, and also by utilizing technological advances, will always try to illegally import drugs into Indonesia, a lucrative and potential drug market.

Amnesty International Indonesia itself notes, courts in Indonesia have sentenced 84 death sentences throughout 2017 to the end of 2018. Of these, 47 sentences were issued in 2017 and the remainder in 2018. The highest number of sentences occurred in 2016, 60 cases. While in 2015, the number decreased to 46 sentences. Then, for 2014, there were 6 sentences, 16 in 2013, and 12 death sentences throughout 2012. Until now, there are at least 300 death row inmates awaiting execution. Based on data from the National Narcotics Agency (BNN) there are currently 60 convicted drug cases that have been decided to be approved and are awaiting execution time. This number does not include the number of people who were executed on April 29, 2015. As many as the freedom of death row inmates have been executed in Nusakambangan, Cilacap, Central Java. They are Nigerian citizens, Jamiu Owolabi Abashin, better known as Raheem Agbage Salami, Okwudili Oyatanze, Martin Anderson, and Silvester Obiekwe Nwolise. There are also Bali Nine duo Andrew Chan and Myuran Sukumaran, Rodrigo Gularte from Brazil, and Zainal Abidin from Indonesia. 
The death penalty can have a deterrent effect on drug dealers. Indonesia has established rules in Law Number 35 Year 2009 concerning Narcotics.

\section{5) Narcotics Distribution in the Southeast Asian Region}

ASEAN countries agreed to establish a Narcotic Board organization. The Narcotic Board is expected to be in accordance with the characteristics of the narcotics problems and law enforcement of each country, which eventually became the forerunner to the birth of the National Narcotics Agency of the Republic of Indonesia (BNN RI).

Based on The Narcotics Drug and Psychotropic Substance Law for ASEAN (27-January-2013), the following are some of the penalties for drug sales activities agreed by ASEAN members as follows:

1. Cultivation, processing, transportation, distribution, delivery, transfer, forced to cause abuse, bad behavior towards narcotics drugs, and psychotropic exhabits substances. 5 years in prison minimum, a maximum of 10 years, and may also be subject to fines.

2. Having narcotics for resale with a minimum sentence of 10 years in prison, the term of imprisonment is not limited to the maximum

3. Production, distribution, sale, import, and export of narcotics are punishable by a minimum of 15 years imprisonment, a maximum period of imprisonment or death.

The 2016 United Nations Convention against Transnational Organized Crime (UNCTOC) as a means of creating international treaties that are law-making treaties. At UNCTOC, it is not rigidly regulated as an understanding of "transnational organized crime" and does not also contain a list of criminal acts that can be classified into it. This is probably due to the applicable laws in each country, such as the example of the use of narcotics in the type of methamphetamine legalized in California, United States, while the narcotics trade in methamphetamine types is prohibited by the Indonesian government.

As a result of the blurring of norms that occur in the drafting of laws regarding the illicit trafficking of narcotics in the Southeast Asian region, causing some blurring of norms in Southeast Asian Countries. This causes the application of different legal sanctions between countries and makes the rules that have been established in international agreements experience vague norms.

International narcotics law regulations that apply in ASEAN have been determined through meetings between countries such as ASOD (ASEAN Senior Officials on Drug Matters) and ASEANAPOL (ASEAN Chiefs of National Police). In addition to the mutually agreed legal regulations, there are legal regulations that apply in each country.

\section{Countermeasures in the Phase of Drug Use}

Users who have already consumed drugs can be placed as victims of drug crimes. These users do not have to be seen or ignored in the community, but must be endeavored so that users become recovered and can live healthy without drugs. Countermeasures for users who have already done this is rehabilitation.

\section{1). Knowing Drug Rehabilitation Sites and Procedures}

For rehabilitation issues, it has been stated in Article 54 of Law Number 35 Year 2009 concerning Narcotics, following up on it, also issued a Supreme Court Circular Letter (SEMA) Number 4 of 2010 
Siringoringo, P. (2020). Countermeasure Against International Drug Crimes In The Perspective Of Indonesian Criminal Law. Advances in Social Sciences Research Journal, 7(5) 251-269.

concerning the placement of abusers, victims of narcotics abuse into medical and social institutions. Strengthened with government support that is not half-hearted, then also issued Government Regulation (PP) No. 25 of 2011 concerning the Implementation of the Obligatory Report of Narcotics Addicts to get therapy and rehabilitation services. So the Indonesian Minister of Health issued a Minister of Health Decree (Kepmenkes) Number 1305 / menkes / SK / VI / 2011 which appointed 131 IPWL in 33 Provinces.

The Law, SEMA, and PP are as a concrete step by the government in an effort to save the next generation from the bondage of narcotics and other illegal drugs, so that the Indonesian Nation does not experience more Lost Generation. For the first step, to get rehabilitation services from the government, quoted from the BNN brochure on Rehabilitation, residents are required to report themselves, there are two ways of reporting mechanisms of BNN IPWL, including:

1. Voluntary, addicts report themselves out of their own awareness, will first undergo an assessment by undergoing interviews, observations, physical examinations, psychological, to obtain information and history of addicts as supporting material for further therapy. After the assessment, undergo an administrative process and be placed in an agreed therapy and rehabilitation center without going through a legal process.

2. The Compulsory Reporting Program for suspects, for addicts who have been handled by investigators, will undergo an assessment first, if it is proven to be related to the drug crime network, it will be legally processed.

Rehabilitation requirements are very easy for administration, only the following files are needed: photocopy of Family Card (KK), photocopy of a resident candidate (Rehabilited Patient) and Parent, Two $4 \times 6$ photo pass, 6,000 two stamp duty stamp, for the resident with the court decision, must bring the complete court decision file.

Resident criteria that can be rehabilitated at UPT T\&R BNN

- Prospective residents are active users with a last use of less than 12 months through a positive urine test, if the last use is less than 3 months, must attach a certificate from a doctor explaining that the person concerned is a drug user.

- Aged 15-40 years, if less than 15 years only undergo detoxification and entry units.

- Not pregnant (For prospective female residents)

- Do not suffer from physical illness (Diabetes Mellitus, Stroke, Heart) or chronic psychological (which can interfere with the program)

- Prospective residents come accompanied by parents/guardians

- If involved in legal matters, prospective residents must have a court decision.

- Prospective residents of court decisions must be accompanied by the court.

\section{Rehabilitation Provisions}

1. The residency coaching period for 6 months includes detoxification, entry units, primary programs, re-entry. Before the whole program, residents are not allowed to go home.

2. While in the detox and entry unit rooms, residents cannot be contacted or visited. Family and resident communication is facilitated by BNN. 
3. Residents can be visited if they have gone through the primary and re-entry phases

4. If the resident escapes from the institution and returns to the family, then the family is obliged to report to the UPT T\&R BNN and send him back to undergo the rehabilitation process.rehabilitasi.

\section{2). Drug Rehabilitation Centers}

In addition to rehabilitation centers provided by the government, which are government hospitals for addicts who voluntarily want to be rehabilitated, there are also rehabilitation places established by the community independently, rehabilitation sites that are established independently by the community, usually they are moved by the situation in the area that is very alarming with an increasing number of drug users. For example, the Galilee Drug Rehabilitation Institution registered with the Social Service on May 28, 2002, aims to save the next generation by providing expertise to work and deepen the spirit according to resident beliefs, Galilee has a religious and Therapeutic Community (TC) based program. Facilities owned by Galilee also have standards, there are offices, meeting rooms, male and female dormitories, kitchens, operational vehicles, "pendopo"[ a wideopen building (without borders or barriers), located at the front of the house, provided for meetings, meetings, equipment, and other purposes related to community needs] and other supporting facilities. By knowing the condition of drug rehabilitation institutions and their rehabilitation processes, it is hoped that the community will have a broader view of the importance of rehabilitation for addicts. That when undergoing the rehabilitation process, it is not as scary as imagined by the general public.

\section{Countermeasures in the Law Enforcement Phase of Drug Crimes 1) Addicts, Abuse, and Victims of Narcotics Abuse}

In the Indonesian Narcotics Law, there are at least 4 (four) meanings for narcotics users, namely addicts, abusers, victims of abuse, and narcotics patients. Narcotics addicts are defined as people who use or abuse narcotics and in a state of dependence on narcotics, both physically and psychologically, while abusers are people who use narcotics without rights or against the law. Then, a victim of narcotics abuse is interpreted as someone who accidentally used narcotics because he was persuaded, tricked, tricked, forced, and/or threatened to use narcotics. To the patient, no understanding was found. However, when referring to Article 53 of the Indonesian Narcotics Act, it can be interpreted that the patient is a person who is given the right to own, store and/or carry narcotics in limited quantities and types in accordance with the doctor's approval for the sake of treatment.

\section{2) Forced Efforts for Narcotics Users}

In general, forced efforts in narcotic crimes refer to Law No. 8 of 1981 concerning the Criminal Procedure Code (hereinafter referred to as the Criminal Procedure Code). This section will elaborate on the regulation of forced efforts in the Criminal Procedure Code, in general, relating to the provisions in the Narcotics Law. Emphasis is placed on forced efforts regulated in the Narcotics Act as a special provision (lexspecialis) as well as responses and criticisms of it.

\section{(1) Arrest}

Arrest is a form of forced effort whose authority is inherent in the investigator. As a general provision (legi generalie), arrests are regulated in the Criminal Procedure Code against all types of criminal acts and their authority is inherent in the investigator. Investigators in the Criminal Procedure Code are officials of the Indonesian National Police or certain civil servant officials who are given special authority by law to conduct an investigation. These provisions provide the basis 
Siringoringo, P. (2020). Countermeasure Against International Drug Crimes In The Perspective Of Indonesian Criminal Law. Advances in Social Sciences Research Journal, 7(5) 251-269.

that investigators can be specifically appointed based on a law. In the Narcotics Law, the special investigator formed is the National Narcotics Agency (hereinafter referred to as BNN).

The Narcotics Law gives the authority to make forced arrest efforts to at least 3 (three) institutions of law enforcement officers. The three institutions are the Police, BNN, and Civil Servant Investigators. Each of these institutions can make an arrest for investigation purposes. This time, the highlight was related to the arrest period and the authority of the institution.

Regarding the time period in arresting by BNN investigators based on Article 75 letter $\mathrm{g}$ as well as Article 76 paragraph (1) and (2) of the Narcotics Law where BNN investigators are given the authority to make arrests of someone suspected of illicit abuse and illicit trafficking of narcotics and narcotics precursors. The exercise of the arresting authority can be carried out no later than $3 \times 24$ (three times twenty-four) hours from the moment the arrest warrant is received by the investigator. The arrest can be extended for a maximum of $3 \times 24$ (three times twenty four) hours.

There is a difference in the length of time in arresting between BNN investigators and Polri investigators or civil servant investigators (other than BNN). Although Article 81 of the Narcotics Law states that investigators of the Republic of Indonesia's National Police and BNN investigators jointly have the authority to conduct an investigation of the misuse and illicit trafficking of narcotics and narcotics precursors based on Narcotics Law. The Narcotics Law does not regulate the authority of the National Police investigator regarding the period of arrest. Because the nature of the legal procedure in the Narcotics Act is a special provision of the Criminal Procedure Code, the time period for arrest by police investigators who are not regulated in the Narcotics Law still refers to the Criminal Procedure Code. Therefore, in accordance with Article 19 paragraph (1) of the Criminal Procedure Code, the period of arrest by an Indonesian police investigator is 1 (one) day.

Civil servant investigators to make arrests referred to in Article 82 paragraph (2) letter $\mathrm{h}$ of the Narcotics Act. However, it is also not clear how long the arrest period will be. So as is the case with Polri investigators, regarding the period of time in making arrests by civil servant investigators also refers to the provisions of Article 19 paragraph (1) of the Criminal Procedure Code, which is within 1 (one) day.

The length of time for making this extended arrest has consequences for the implementation of the forced effort. Setting a period of 1 (one) day in the Criminal Procedure Code is not without reason. Where the principle is that arrest of a person based on sufficient preliminary evidence must be done as soon as possible (promptly). It appears at first, the formation of the Narcotics Law prolonged the arrest period by considering the difficulty of disclosure of narcotics crimes, especially the distribution of drugs carried out systematically and organized. However, in practice, this provision has a significant impact on users who are not narcotics dealers.

With the duration of this arrest the opportunity for a narcotics user to become a target of arrest with a strategy of trapping (trapping). It should be noted that the arrest warrant must contain the subject and object of the arrest. If the arrest is not made as soon as possible then the opportunity for this extended period of time is used to gather strong evidence so that narcotics users (whose names have been included in the arrest warrant) can be charged. The arrest is then directed at the 
state of the perpetrators caught red-handed. Narcotics users will find it more difficult to dodge if evidence is found on them and added to the results of laboratory tests that show positive results.

This is not balanced by an adequate oversight mechanism and aims to ascertain and supervise whether the length of the arrest is due to the difficulty of disclosing narcotic crimes or in the interest of strengthening the evidence to ensnare the perpetrators. If examined, Article 76 paragraphs (1) and (2) of the Narcotics Law do not provide clear regulations regarding who gives an arrest warrant to the investigator and where approval for the extension of the arrest period is submitted. In the absence of clear arrangements, it can be concluded that the arrest warrant to the investigator was given by the investigator's superior. Likewise with the approval of the extension of the arrest period. Urgensi pembahasan terhadap persoalan ini adalah untuk menjawab pertanyaan bagaimana skema pengawasan terhadap kewenangan penangkapan oleh penyidik. Jawabannya adalah dilakukan oleh 17atasan atau institusi penyidik itu sendiri. Pertanyaan lanjutannya yaitu apa konsekuensinya apabilapenangkapan tidak berhasil atau tidak dilakukan oleh penyidik dalam jangka waktu tersebut. Hal initidak ditemukan jawabannya dalam UU Narkotika.

Principlly, this certainly is closely related to one's human rights. Especially if the arrest is preceded by surveillance. The lack of surveillance schemes and the consequences of the time period for making these arrests, in addition to being used for the purpose of snaring offenders, also open up the potential for surveillance without a time limit. Moreover, there is a trend of arrests of narcotics offenders carried out by being caught red-handed.

In addition, the authority to make arrests by civil servant investigators also needs to be examined. In Article 82 paragraph (2) subparagraph h of the Narcotics Law as mentioned above, it is stated that investigators for civil servants are authorized to make arrests. However, the Narcotics Law does not state whether the implementation of the forced effort can be carried out directly or not by civil servant investigators.

Narcotics Law, through Article 83 and Article 85, only stipulates that investigators can work together to prevent and eradicate the abuse and illicit trafficking of narcotics and narcotics precursors. In addition, the Narcotics Law only regulates the investigation of narcotics abuse and narcotics precursors, civil service investigators coordinate with BNN investigators or Polri investigators in accordance with the Law on Criminal Procedure. When referring to Article 18 paragraph (1) of the Criminal Procedure Code, the implementation of the arresting authority is carried out through Police officers.

\section{(2) Detention}

Concerning forced detention efforts, the Narcotics Act does not provide a specific arrangement for the arrest. Therefore, the forced effort refers to the regulation in the Criminal Procedure Code. The emphasis is placed on the rationality of detention, the type of detention for the use of narcotics, and the length of detention, especially in the pre-trial stage. In the structure of the Criminal Procedure Code, detention can begin from the pre-trial phase, namely in the investigation stage to the examination in court hearings, both the District Court, the High Court, and the Supreme Court. Detention is regulated in Article 20 to Article 31 of the Criminal Procedure Code. Detention in the Criminal Procedure Code is defined as the placement of a suspect or defendant in a certain place by 
Siringoringo, P. (2020). Countermeasure Against International Drug Crimes In The Perspective Of Indonesian Criminal Law. Advances in Social Sciences Research Journal, 7(5) 251-269.

an investigator or public prosecutor or judge by stipulation, in the case of the case according to the manner stipulated in this law (KUHAP).

Detention in the Criminal Procedure Code is based on three interests. First, detention is based on the interests of the investigation. It was stated that the investigator or assistant investigator on orders from the investigator was authorized to make a detention. Detention for the purpose of this investigation depends on the needs of the investigator in carrying out the examination function at the investigation stage. This means that if the investigation is sufficient, then detention is no longer necessary unless there is another reason to keep the suspect detained. Second, detention based on the interests of the prosecution. Third, detention is based on the importance of a court hearing. This detention is aimed at facilitating the hearing in a court of law. The judge has the authority to make a detention based on whether the detention is necessary or not, in accordance with the interests of the hearing at a court hearing. The basis of detention includes the legal basis, conditions and conditions that provide the possibility for law enforcement and judges to carry out detention. All these elements are interrelated so that if one of the elements is not present, then the detention action does not meet the principle of legality.

The first element in detention is the juridical element. The law has determined both in general and in detail any of the criminal acts, the perpetrators may be subject to detention. Article 21 paragraph (4) of the Criminal Procedure Code states that detention can only be imposed on suspects or defendants who commit criminal acts and/or trials or provide assistance in criminal acts. The detention can be carried out if (i) the crime is threatened with imprisonment of five years or more; and (ii) the perpetrator commits a crime specifically mentioned in the article in the Criminal Code (KUHP) and special criminal law.

The next element is the element of circumstances that cause anxiety. This element focuses on the situation or need for detention in terms of the circumstances which include the suspect or defendant himself. The conditions or requirements for detention are determined in Article 21 paragraph (1) of the Criminal Procedure Code which is in the form of a situation that raises concerns that the suspect or defendant will (i) run away, (ii) damage or eliminate evidence, and or (iii) repeat the crime. All of these conditions are basically assessed subjectively by law enforcement officers based on objective situations.

The last element is the element of certain conditions. Detention can be carried out if it meets the requirements as stated in Article 21 paragraph (1) of the Criminal Procedure Code. Where detention can be carried out against suspects or defendants who are allegedly suspected as perpetrators of a criminal offense and the allegations that are hard are based on sufficient evidence.

What must be considered in this element is the understanding that the terms of detention are different from the conditions of arrest. The difference lies in the quality of the evidence. On arrest this evidence requirement is based on sufficient preliminary evidence, whereas detention is based on sufficient evidence. Thus, the conditions of evidence in detention should be of higher quality than evidence in making arrests.

In the Criminal Procedure Code there is no explanation regarding sufficient evidence. Provisions that can be used as references are Article 62 paragraph (1) and Article 75 Herziene Inlandsch 
Regulation (HIR). HIR states that the requirement for evidence to be able to carry out detention against a suspect or defendant is based on a benchmark that there is "sufficient evidence" in declaring that the suspect or defendant is guilty. The lack of clarity in the Criminal Procedure Code in determining the parameters of sufficient evidence causes this to be seen proportionally related to Article 184 of the Criminal Procedure Code.

In addition, the Criminal Procedure Code contains provisions regarding further detention. The procedure for detention or further detention carried out by investigators, public prosecutors, and judges is regulated in Article 21 paragraph (2) and (3) of the Criminal Procedure Code. Detention or further detention is carried out by the investigator or public prosecutor against the suspect/defendant by providing a detention warrant or stipulation of a judge stating the identity of the suspect/defendant and stating the reasons for detention as well as a brief description of the crime case alleged or charged and place of detention. A copy of the arrest warrant or further detention or determination of the judge must be given to his family. In terms of types of detention, the Criminal Procedure Code determines three types of detention as regulated in Article 22 paragraph (1) of the Criminal Procedure Code. According to this provision, the type of detention can be in the form of: (i) detention of a state prison (detention); (ii) house arrest; and (iii) city arrest. On the time side, the Criminal Procedure Code provides time limitation in detention.

In the investigation stage, based on Article 24 paragraph (1) of the Criminal Procedure Code, investigators can detain for a period of 20 days. If needed, for the sake of unfinished investigation, investigators can request an extension to the public prosecutor for a maximum period of 40 days (Article 24 paragraph (2) of the Criminal Procedure Code). Therefore, the maximum period of detention at the investigation stage is 60 days.

Then, the period of detention at the prosecution level. Based on Article 25 paragraph (1) of the Criminal Procedure Code, Public Prosecutors can carry out detention for a maximum period of 20 days. The Public Prosecutor may request an extension of detention to the Chair of the District Court. This extension is given for a maximum period of 30 days (Article 25 paragraph (2) of the Criminal Procedure Code). This extension is requested by the public prosecutor in the interests of the prosecution that has not yet been completed. The Public Prosecutor can hold for a maximum of 50 days.

The next is detention during the examination process at the trial. Detention can be carried out at any level of trial, starting from the District Court, the High Court, and the Supreme Court. For the purpose of examination, the District Court has the authority to issue a detention determination letter for a maximum period of 30 days (Article 26 paragraph (1) of the Criminal Procedure Code). If detention is still needed for the purpose of examination at the hearing, the judge concerned may request an extension to the Chair of the District Court. The extension is for a maximum period of 60 days. Overall, detention in the District Court is conducted for a maximum period of 90 days.

At the High Court level, detention can be done for a maximum of 30 days and can be extended for a maximum period of 60 days, so that detention in the High Court can be made no more than 90 days. At the Supreme Court level, detention is carried out for a maximum period of 50 days and can be extended for 60 days. Thus, in the Supreme Court the detention can be carried out for a maximum period of 110 days. 
Siringoringo, P. (2020). Countermeasure Against International Drug Crimes In The Perspective Of Indonesian Criminal Law. Advances in Social Sciences Research Journal, 7(5) 251-269.

Jika masa penahanan dijumlahkan secara keseluruhan, mulai dari pemeriksaan di If the total detention period is added up, starting from investigations at the investigation, prosecution, to court hearings (District Court, High Court, and Supreme Court), then the total length of time for detention is 400 days. If this time limit has been reached, even though the case investigation has not yet been completed, the suspect/defendant must be released from detention by law without being burdened by certain conditions and procedures. The suspect/defendant's order must be issued from detention by law without being burdened by certain conditions and procedures if it has passed the maximum time period in conducting detention also applies at each stage of the examination at each level.

The attention needs to be given to pre-trial detention. The first thing to note is the rationality of detention for narcotics users. When viewed from the construction of the Narcotics Law, where the formulation of articles and subjects of the crime is very loose coupled with a criminal threat that has an average of more than 5 (five) years, the detention of narcotics users seems compulsory to be carried out because it meets the objective elements.

What if the narcotics offender is placed in a rehabilitation institution both medical and social. Does the placement period count as a detention period, so that there is no detention of a second time. Article 103 paragraph (2) of the Narcotics Law states that the period of undergoing treatment and / or treatment for narcotics addicts is calculated as serving time. Placement of narcotics users in rehabilitation institutions during detention often becomes polemic because so far the mindset that was built that delivery or placement of prisoners in the hospital does not count as a period of detention. The main reason is that the Criminal Procedure Code only recognizes three types of detention, namely the detention of state detention centers (detention centers), house detention, and city detention as stipulated in Article 22 paragraph (1) of the Criminal Procedure Code.

This understanding is then more or less influenced by the actions of investigators and public prosecutors who preferred placing addicts and narcotics users in detention centers. Whereas putting addicts and narcotics users in detention centers have a very negative impact on those concerned. In this regard, the Supreme Court has responded, during Law No. 22 of 1997 and Law No. 5 of 1997 applies, basically the Supreme Court has realized that the incarceration of drug addicts and drug users is not the right step because it is more appropriate to prioritize the interests of care and treatment, further aggravated by conditions of detention that are not supportive.

Placement of criminal offenders in rehabilitation institutions both medical and social is counted as a detention period. The basis of the argument is contained in the Elucidation of Article 21 paragraph (4) letter $b$ of the Criminal Procedure Code, which states that a suspect or accused of a drug addict is being held in a particular place which is also a place of treatment. Since placement in a rehabilitation institution is counted as a detention period, the consequence is that if the detention is carried out after the rehabilitation period is completed, it must take into account the time of placement in the rehabilitation institution so that the detention does not exceed the maximum time limit, and if later the person concerned is brought before the trial and terminated to serve a prison sentence, then in accordance with Article 22 paragraph (4) of the Criminal Procedure Code, the period of detention in the place of care is deducted entirely from the criminal sentence imposed. 


\section{3) Punishment for Narcotics Users \\ (1) Tendency of Article Used}

In its application, there are several articles in the Narcotics Law which are often imposed by the Public Prosecutor, both in the indictment and in the lawsuit. Starting from Article 111, Article 112, Article 114, and Article 127 of the Narcotics Law. The tendency for the use of articles and the formulation of the indictment with the indictment of the subsidarity has a significant influence on the placement of a narcotics user in a rehabilitation institution, both medical and social. The following are some of the articles which tend to be used. Article 111 paragraph (1) of the Narcotics Act reads"Anyone who is without the right or violates the law of planting, maintaining, possessing, storing, controlling, or providing Class I narcotics in the form of plants, shall be sentenced to a minimum of 4 (four) years imprisonment and a maximum of 12 (twelve) years and criminal a minimum fine of Rp. 800,000,000.00 (eight hundred million rupiah) and a maximum of Rp. 8,000,000,000.00 (eight billion rupiah)."

The difference with Article 112 paragraph (1) of Narcotics Law is in the form of narcotics, which is in the form of plants or not plants. Article 112 paragraph (1) of Narcotics Law reads "Every person without rights or against the law owns, stores, controls, or provides Narcotics Category I is not a plant, shall be sentenced to a maximum of 4 (four) years imprisonment and a maximum of 12 (twelve) years ) year and a minimum fine of Rp. 800,000,000.00 (eight hundred million rupiah) and a maximum of Rp. 8,000,000,000.00 (eight billion rupiah). " Then, Article 114 paragraph (1) of the Narcotics Act states that "Any person without rights or against the law offers to sell, sell, buy, accept, be an intermediary in buying and selling, exchanging or handing over narcotics of Group I, sentenced to imprisonment for life imprisonment life sentence or imprisonment for a minimum of 5 (five) years and a maximum of 20 (twenty) years and a fine of at least Rp 1,000,000.00 (one billion rupiah) and a maximum of Rp 10,000,000,000.00 (ten billion rupiah).

"The three articles tend to be placed in primary indictments. In addition to its broader elements and greater opportunities to ensnare perpetrators, this also has consequences for the closed possibilities for narcotics users to be placed in medical and social rehabilitation institutions.

It is different if the article tends to be applied in the primary indictment is Article 127 of the Narcotics Law which states "Every Abuser: (a) Narcotics of Group I shall themselves be sentenced to a maximum imprisonment of 4 (four) years; (b) Narcotics of Group II shall be sentenced themselves to a maximum imprisonment of 2 (two) years, and (c) Narcotics of Group III shall be sentenced themselves to a maximum imprisonment of 1 (one) year. "

The article is an integral part of Article 127 paragraph (2) of the Narcotics Law which states that in deciding on a case as referred to in paragraph (1), the judge must pay attention to the provisions referred to in Article 54, Article 55, and Article 103 of the Narcotics Law. These articles require and provide guidelines for judges to place drug users in medical and social rehabilitation institutions.

From the tendency of the formulation of the indictment article used by the Public Prosecutor it can be said that the approach to the imprisonment of narcotics users is more dominant than placing users in rehabilitation institutions both medically and socially. Besides, the trend towards the imposition of Article 111, Article 112, and Article 114 of the Narcotics Law also brings a 
Siringoringo, P. (2020). Countermeasure Against International Drug Crimes In The Perspective Of Indonesian Criminal Law. Advances in Social Sciences Research Journal, 7(5) 251-269.

considerable impact on the detention of narcotics users. Criminal threats in Article 111 and Article 112 of the Narcotics Law which have a minimum of 4 (four) years and a maximum of 12 (twelve) years while Article 114 with a minimum threat of 5 (five) years and a maximum of 20 (twenty) years causes detention of narcotics users done because it meets the objective element.

Next is the formulation of a very loose article in the Article 111 and Article 112 of the Narcotics Law. Such formulation is contrary to principle lex certa and lex stricta are derived from the principles of the rule of law. The two articles cannot distinguish between narcotics users and non-narcotics users.

\section{(2) Criminal Sanction Formulation}

From the formulation of criminal sanctions in the Narcotics Law, several forms of criminal sanctions are found. Broadly speaking, in the Narcotics Law, the formulation of criminal sanctions includes the formulation of a single, cumulative, alternative, and cumulative-alternative.

A single formulation of a criminal sanction system is a formulation system that only contains one type of punishment. This can be seen in Article 127 paragraph (1) of the Narcotics Law. Article 127 paragraph (1) of the Narcotics Law reads, "Every Use of Abuse. Narcotics of Group I shall be sentenced themselves to a maximum imprisonment of 4 (four) years, b. Narcotics of Group II for themselves shall be sentenced to a maximum imprisonment of 2 (two) years, and c. Narcotics Group III for yourself sentenced to a maximum imprisonment of 1 (one) year. "The second formulation of criminal sanctions is a cumulative formulation, which means the formulation is carried out by combining several types of criminal sanctions. For example, imprisonment and fines. In the Narcotics Act, this can be seen in Article 126 paragraph (1) of the Narcotics Act. Article 126 paragraph (1) of the Narcotics Law states, "Any person who without rights or violates the law uses Narcotics Group III against another person or provides Narcotics Group III for use by others, is convicted with imprisonment for a minimum of 3 (three) years and a maximum of 10 (ten) years and a fine of imprisonment of at least Rp. 600,000,000.00 (six hundred million rupiah) and a maximum of Rp. 5,000,000,000.00 (five billion rupiah). "

The next system of formulation of criminal sanctions is an alternative formulation where the formulation system provides an alternative type of punishment that will be used by the public prosecutor in formulating a claim or providing an alternative for judges to render a decision. For example, imprisonment or fines. In the Narcotics Law, the formulation can be seen in Article 128 (1) of the Narcotics Act. Article 128 paragraph (1) of the Narcotics Act states "Parents or guardians of addicts who are not yet of age, as referred to in Article 55 paragraph (1) who intentionally does not report being sentenced to a maximum imprisonment of 6 (six) months or a maximum fine Rp 1,000,000,000.00 (one billion rupiah). "

The last, the cumulative-alternative formulation of criminal sanctions. Where the formulation system is done by combining several types of crimes at once provide alternative options. For example, capital punishment, life imprisonment or imprisonment, and fines. In the Narcotics Law, this can be seen in Article 116 paragraph (2) Narcotics Law. Article 116 paragraph (2) of the Narcotics Law states that "In the case of the use of narcotics against other people or the provision of Narcotics Group I for the use of other people as referred to in paragraph (1) resulting in another person dying or permanently disabled, the offender is sentenced to a death sentence, life 
imprisonment, or a prison sentence of at least 5 ( five years and a maximum of 20 (twenty) years and a maximum criminal penalty as referred to in paragraph (1) plus 1/3 (one third)."

\section{(3) Formulation of Duration of Criminal Sanctions}

Next, the system of formulation of the duration of criminal sanctions will be elaborated. In the Narcotics Law there are 2 (two) types of systems for the formulation of the length of criminal sanctions. The first formulation system is a maximum system (fixed / indefinite sentence system). This formulation is carried out by determining the maximum threat of criminal length. In the Narcotics Law, this can be seen in Article 134 paragraph (1) of the Narcotics Act. The article states that "Narcotics addicts who are old enough and deliberately did not report themselves as referred to in Article 55 paragraph (2) shall be sentenced to a maximum imprisonment of 6 (six) months or a maximum imprisonment of Rp 2,000,000.00 (two million rupiahs)".

Second is the system of formulating the duration of criminal sanctions by determining the minimum and maximum limits of criminal threats. This is also known as the determinate sentence system. In the Narcotics Law, this formulation system can be seen in Article 121 paragraph (1) of the Narcotics Law, which reads "Any person who is not entitled or unlawful uses Narcotics Group II against another person or provides Narcotics Group II for use by others, convicted with imprisonment a minimum of 4 (four) years and a maximum of 12 (twelve) years and a criminal fine of at least Rp. 800,000,000.00 (eight hundred million rupiah) and a maximum of Rp. 8,000,000,000.00 (eight billion rupiah). "

\section{4) Rehabilitation Policy for Narcotics Users}

By referring to Article 4 of the Narcotics Law, it can be obtained that rehabilitation is one of the main objectives of the promulgation of the Narcotics Law. Even the regulation on rehabilitation has its own part, namely in Chapter IX the second part about Rehabilitation. Starting from Article 54 to Article 59 the Narcotics Law regulates the rehabilitation of narcotics users, in addition to being spread in various other articles. Article 54 of the Narcotics Law states that drug addicts and victims drug abuse, rehabilitation is mandatory. The obligatory nature of rehabilitation should be the main benchmark for law enforcement officials and judges in taking action against narcotics users. Article 54 of the Narcotics Act is closely related to Article 127 of the Narcotics Act. In Article 127 paragraph (2) of the Narcotics Law it is stated that judges must pay attention to the provisions of Article 54, Article 55, and Article 103 of the Narcotics Law in issuing decisions. However, although it is mandatory, in its implementation it is very dependent on investigators and public prosecutors. If the Public Prosecutor does not use the provisions of Article 127 of the Narcotics Law in the indictment or charge, then the placement of narcotics users in rehabilitation institutions is difficult. Including the most fatal conditions, where the judge still decided to use Article 127 of the Narcotics Act but did not consider the rehabilitation provisions as stated in article 54 of the Narcotics Act.

Likewise with the tendency of public prosecutors and judges to prefer narcotics users as perpetrators of crime. The basis is that it is impossible for an abuser, in his act of abuse, he does not carry, buy, store, and have drugs, especially if the perpetrator is caught and found evidence.

\section{CONCLUSION}

This drug use in terms of any side has a significant negative impact, and therefore this needs to be campaigned. Many of us have to reflect on the issue of drug addiction. We usually associate addiction 
Siringoringo, P. (2020). Countermeasure Against International Drug Crimes In The Perspective Of Indonesian Criminal Law. Advances in Social Sciences Research Journal, 7(5) 251-269.

with weak faith and self-control. However, the real reason behind their decision to use drugs is far more complex than just moral damage.

Lack of understanding of what are the risk factors and causes of a person to become a drug addict makes many people blinded by prejudice. Someone who falls in the trap of opium is powerless to control his desires and behavior. That is why people who are trying to get out of addictions need to get support and love, not to be ostracized or judged. Drug handling is not only a national issue, it is also an international crime, therefore good cooperation between countries is needed to prevent drugs in the prevention phase, the law enforcement phase, and the rehabilitation phase for those who are truly victims of drug crimes.

\section{References}

Berta, Ani. 2014. Mengenal Tempat Rehabilitasi Narkoba Dan Prosedurnya. Diakses dari https://www.fimela.com/news-entertainment/read/3511315/mengenal-tempatrehabilitasi-narkoba-dan-prosedurnya pada tanggal 7 Agustus 2019.

Badan Narkotika Nasional (BNN). 2014. Laporan Akhir Survei Nasional Perkembangan Penyalahguna Narkoba Tahun Anggaran 2014.

CNN Indonesia. 2019. BNN Ingatkan 50 Orang Meninggal Setiap Hari karena Narkoba. https://www.cnnindonesia.com/nasional/20150429202212-12-50148/bnn-ingatkan-50- orang-meninggal-setiaphari-karena-narkoba/, diakses pada tanggal 7 Agustus 2019.

Harahap, M. Yahya 2009. Pembahasan Permasalahan dan Penerapan KUHAP: Penyidikan dan Penuntutan. Sinar Grafika. Jakarta.

Direktorat KIPS. $2019 . \quad$ Kejahatan Lintas Negara, diakses dari https://kemlu.go.id/portal/id/read/89/halaman_list_lainnya/kejahatan-lintas-negara pada 20 November 2019.

Institute for Criminal Justice Reform (ICJR). 2014. Peraturan Bersama Penanganan Pecandu Narkotika Dan Korban Penyalahgunaan Narkotika Ke Dalam Lembaga Rehabilitasi, diakses dari http://icjr.or.id/peraturan-bersamapenanganan-pecandu-narkotika-dan- korban-penyalahgunaan-narkotika-ke-dalam-lembaga-rehabilitasi/_ pada tanggal 7 Agustus 2019.

Muhamad, S. Victor. 2015. Kejahatan Transnasional Penyelundupan Narkoba Dari Malaysia Ke Indonesia. Politica Vol. 6 No. 1 Maret 2015

Savitri, Tania. 2017. 4 Faktor Psikologis yang Membuat Seseorang Menjadi Pengguna Narkoba. Diakses dari https://hellosehat.com/hidup-sehat/alasan-pecandu-narkoba-kecanduan/

pada tanggal 7 Agustus 2019.

Sclar, Kindra. 2017. 11 Real Reasons Why Teenagers Experiment with Drugs. Diakses dari https://drugabuse.com/11real-reasons-teenagers-experiment-drugs/ pada tanggal 7 Agustus 2019.

Suatra, Putrawan, et al. 2017. Pengaturan Hukum Tindak Pidana Narkotika Sebagai Kejahatan Trans Nasional di Kawasan Asia Tenggara. Jurnal Hukum Universitas Udayana

Widodo, E. Supriyadi, et al. 2016. Meninjau Rehabilitasi Pengguna Narkotika dalam Praktik Peradilan. Institute for Criminal Justice Reform. ISBN: 978-602-6909-35-0. 


\section{Regulations:}

- Law No. 8 of 1981 concerning the Criminal Procedure Code

- Law Number 35 of 2009 concerning Narcotics

- Government Regulation No. 25 of 2011 concerning the Implementation of the Obligatory Report of Narcotics Addicts

- Joint Regulation of the Chief Justice of the Supreme Court, Minister of Law and Human Rights, Minister of Health, Minister of Social Affairs, Attorney General, Chief of Police of the Republic of Indonesia, and Head of BNN regarding the Handling of Narcotics Addicts and Victims of Narcotics Abuse into Rehabilitation Institutions 